Ties of Resistance and Cooperation. Aedemon, Lusius Quietus and the Baquates.

Wouter Vanacker

Universiteit Gent, Faculteit Letteren en Wijsbegeerte, Sint-Pietersnieuwstraat 35, 9000

Gent, Belgium

Wouter.Vanacker@UGent.be

\begin{abstract}
Gaius' decision to dissolve the protectorate of Mauretania and to depose its client king, Ptolemaeus, led to the outbreak of the Revolt of Aedemon (AD 40). This paper will develop a number of innovative thoughts and hypotheses concerning the extent of this rebellion and its possible impact on the deposition of Ptolemaeus, as well as the role of the Romans in its suppression. The main aim is to explore the connection between this revolt, Trajanus' famous general Lusius Quietus (cos. AD 117?), and the Baquates, an indigenous Mauretanian tribe. I will suggest that Lusius Quietus was descended from a chief of a (semi-)nomadic tribe who supported the Roman cause during the Revolt of Aedemon. Considering the setting and dimension of this revolt, as well as the unrest in Mauretania at the time of Lusius Quietus' execution by Hadrianus, I argue that this tribe can be identified as the Baquates. This reconstruction suggests a long-lasting and particularly positive relationship between this tribe and Rome. It allows for a further reconsideration of the relationship between (semi-)nomadic and Roman/sedentary groups in Roman North Africa, to the detriment of one-sided analytical schemes that stress endemic hostility.
\end{abstract}

\title{
Keywords
}

Aedemon, Lusius Quietus, Baquates, Mauretania, nomads, insurgence

\section{Body Text}

\section{Aedemon and the Inhabitants of Mauritania}

It has long been believed that the execution of Ptolemaeus in AD 40 had tremendous consequences in Mauretania. ${ }^{1)}$ The ensuing uprising of Aedemon, a freedman of the client king, has been perceived as a widespread revolt. According to one of the adherents of this view, the entire protectorate took up arms, "das ganze Land wie ein Mann gegen den Kaiser" (Hoffman 1959). Similarly, Rachet stated that both sedentary segments of the population ("citadins, villageois et fermiers") and nomadic tribes supported Aedemon's cause. ${ }^{2)}$ Similar views have been expressed by Harmand ("une insurrection nationale", 1960) and Romanelli (1959).

\footnotetext{
1) On the execution of Ptolemaeus (PIR 2 P 1025): Suet. Calig. $26+35$. Plin. H. N. 5. 11.

${ }^{2)}$ Considering the size of the Revolt of Aedemon (PIR ${ }^{2}$ A 112) she posed: "Tout le pays compris entre les deux résidences royales de Juba II, Volubilis et Iol Caesarea, se dressa contre la mainmise romaine" Rachet, M. 1970. Rome et les Berbères. Un problème militaire d'Auguste à Dioclétien. Collection Latomus. Bruxelles: Latomus..
} 
However, this perception has been subject to criticism. Fishwick, and Kotula before him, emphasised the improbability of such a unified rebellion (Fishwick 1971, Kotula 1964). There are several signs of disloyalty to the Moorish kings amongst the sedentary communities. During the Revolt of Tacfarinas, segments of the sedentary population felt uncomfortable with the fact that Ptolemaeus governed through his freedmen, and some of them rallied to the rebels. ${ }^{3)}$ The incapability of the Moorish kings to control nomadic tribes may also have encouraged sedentary groups to reject Aedemon's aspirations (cf. infra). An inscription attests that even in the country's main administrative centres the revolt was poorly supported. M. Valerius Severus was honoured by the Volubilitani for having led a locally recruited cohors auxiliorum against Ptolemaeus' freedman. ${ }^{4)}$ It has also been related that the heavily Punicised city-dwellers were probably reluctant to accept as their king an adherent of oriental culture (Fishwick 1971, Kotula 1964). This may also imply that the Moorish kings themselves enjoyed limited popularity. ${ }^{5)}$ Finally, the destruction and abandonment of towns in western Mauretania, which have been dated to the late Republic and the early Empire, have been connected with local resistance against Romanisation and the settlement of Roman colonies (Akerraz et al. 1981-1982, Majdoub 1992). ${ }^{6}$

What about the (semi-)nomadic population? Some scholars have believed that the campaigns of Suetonius Paulinus and Hosidius Geta in AD 42, against the Moorish tribe(s) led by Salabos, should be characterised as expeditions "à des fins d'exploration ou d'intimidation" (quote: Frézouls 1980, Kotula 1964). ${ }^{7)}$ Ptolemaeus, the geographer, possibly points to the existence of similar endeavours in unconquered territories that did not directly aim for expansion. ${ }^{8}$ An inscription probably alludes to a similar expedition in Mauretania. ${ }^{9)}$ However, in the case of Salabos this perception contrasts with the perseverance of the Romans, since they continued the military operation even to the point where a disaster due to water shortage was imminent.

It has been questioned whether these campaigns should be connected with the Revolt of Aedemon. ${ }^{10}$ Crucial for this view is Cassius Dio's statement that 'the next year, the same Moors' rose again'. ${ }^{11)}$ Fishwick, however, argued that the two conflicts are not

\footnotetext{
3) Tac. Ann. 4. 23. On this revolt, cf. Sirago 1987.

4) AE 1916. 42.

5) As it has been acknowledged by Coltelloni-Trannoy $(2002,142-4)$ that the culture policy of Ptolemaeus and Juba II (PIR ${ }^{2}$ I 65) was heavily oriented towards the east.

${ }^{6)}$ However, literary and archaeological sources on these destructions have more frequently been interpreted as attestations of warfare at the time of the annexation (cf. infra).

${ }^{7)}$ D. C. 60. 9. 1-5. On these generals, cf. Thomasson 1996, 198-9 [C2,3], PIR ${ }^{2}$ S 957, PIR² H 216.

${ }^{8)}$ Cf. Septimius Flaccus (PIR $\mathrm{S} 451$ ) and, less probably, Iulius Maternus (PIR ${ }^{2}$ I 414) in: Ptol. Geog. 1. 8.

5. Cf. Thomasson 1996, 138-9 [N13].

9) CIL 8. 21567.

10) As proposed by Cagnat Cagnat, R. 1912. L'Armée romaine d'Afrique et l'occupation militaire de l'Afrique sous les empéreurs. Paris: Leroux., Romanelli Romanelli, P. 1959. Storia delle province romane dell'Africa. Istituto italiano per la storia antica. Studi fasc.14. Roma: L'erma di Bretschneider., Harmand Harmand, L., and A. Grenier. 1960. L'Occident romain: Gaule - Espagne - Bretagne - Afrique du Nord (31 av. J.C. à 235 ap. J.C.). Bibliothèque historique. Paris: Payot., and Bénabou Bénabou, M. 1976. La résistance africaine à la romanisation. Textes à l'appui. Histoire classique. Paris: F. Maspero.. Apparently, also Corbier and Griesheimer share this view Corbier, P., and M. Griesheimer. 2005. L'Afrique romaine. 146 av. J.-C. - 439 ap. J.-C. Mondes anciens. Paris: Ellipses..

${ }^{11)}$ D. C. 60.9. 1.
} 
related to each other (Fishwick 1971). ${ }^{12)}$ It is indeed remarkable that Aedemon is not mentioned by Cassius Dio. Confusion becomes paramount if one considers the chronology of the conflict(s). Elsewhere, Dio Cassius suggests that warfare in Mauretania had been concluded before Gaius was succeeded by Claudius. ${ }^{13)}$ But Plinius, whose account dates much closer to the time of the event, relates: Romana arma primum Claudio principe in Mauretania bellavere Ptolemaeum regem a Gaio Caesare interemptum ulciscente liberto Aedemone....! ${ }^{14)}$ The issues of the identity of the rebels and timing of the revolt(s) would have been less obscure if a number of lines in Dio Cassius' narrative had not been lost. ${ }^{15)}$ One should not readily suppose that in the missing section Dio Cassius referred to Aedemon. If he really identified Salabos' revolt with the rebellion of Ptolemaeus' freedman, however, then this could also have been an error, based upon the historian's lack of insight into the complex events at the time of the annexation. On the other hand, it would be an odd coincidence that Plinius also related that generals of consular rank were conducting warfare as far as Mount Atlas, at the time when Aedemon avenged his former master. ${ }^{16)}$ It is possible that Dio Cassius (also) referred to rebellious (semi-)nomadic tribes which, like Ptolemaeus' avenger, took the protectorate's collapse and the subsequent power vacuum as an opportunity to reclaim their independence and/or to extend their power. Every interpretation of the literary sources remains fairly speculative. While one cannot discard the possibility that neither was able to make a distinction between the Revolt of Aedemon and the campaigns against Salabos, Plinius and Dio Cassius do not provide strong arguments against the view that Aedemon and Salabos were allied and shared a common cause.

In order to strengthen his argument, Fishwick has pointed to the fact that the (semi)nomadic groups had proven to be rather unruly subjects of the Moorish kings. The Gaetulians did revolt against Juba's policy during the reign of Augustus. ${ }^{17)}$ The Revolt of Tacfarinas was put down in $\mathrm{AD} 24$, after almost ten years of devastating warfare. ${ }^{18)}$ On both occasions, Roman military support was crucial to crush the rebels.

The view that Aedemon's power was (primarily) based upon nomadic forces is also rendered doubtful by the (abovementioned) inscription that possibly attests Aedemon's intention to capture Volubilis, the most important urban centre in western Mauretania. ${ }^{19)}$

\footnotetext{
12) Similarly, (though confusing by the different chronologies) Rachet (1970, 126 vs. 133-4), as well as Gascou Gascou, J. 1978. La succession des bona vacantia et les tribus romaines de Volubilis. Antiquités africaines 12:109-124., Gutsfeld Gutsfeld, A. 1989. Römische Herrschaft und einheimischer Widerstand in Nordafrika. Stuttgart: Franz Steiner Verlag., Coltelloni-Trannoy Coltelloni-Trannoy, M. 2002. Le royaume de Maurétanie sous Juba II et Ptolémée (25 av. J.C. - 40 ap. J.-C.). Études d'antiquités africaines. Paris: CNRS., Ibba and Traina Ibba, A., and G. Traina. 2006. L'Afrique romaine de l'Atlantique à la Tripolitaine, 69-439 ap. J.C. Collection Histoire ancienne et médiévale. Rosny-sousBois: Bréal..

${ }^{13)}$ D. C. 60. 8. 6.

${ }^{14)}$ Plin. H. N. 5. 11.

${ }^{15)}$ D. C. 59. 25. 1.

${ }^{16)}$ Plin. H. N. 5. 11: ...consulatu perfunctis atque e senatu ducibus qui tum res gessere ... Atlantem penetrasse in gloria fuit.

${ }^{17)}$ D. C. 55. 28. 3-4. Flor. 2. 31. Oros. 6. 21. 18. Vell. 2. 115.

18) Tac. Ann. 2. 52, 3. 20-21 + $32+73-74,4.23-26$.

19) Cf. AE 1916. 42. Euzennat $(1957,51)$ pointed to additional archaeological evidence on destructive warfare at Volubilis, though more recently Lenoir has expressed his doubts about this observation (1989, 92-95).
} 
Volubilis may not have been the only town that witnessed heavy fighting. Plinius mentioned that in his time the towns of Lissa and Cotte in Mauretania Tingitana had been abandoned. ${ }^{20)}$ Archaeologists have discovered severe destructions dating to this period, both at Lixus and Tamuda. ${ }^{21)}$ Of course, it should be mentioned that the identity of the destroyers cannot be reconstructed. Were these towns razed by Aedemon, by his enemies, or by revolting Berber tribes from the Rif? According to Kotula, Aedemon may have tried to gain possession of strategically important cities and ports in this coastal region (Kotula 1964). Kotula's proposal remains highly speculative. The Romans could have conquered and destroyed them as well, because Ptolemaeus' avenger controlled them and/or the Romans intended to cut off supplies or escape routes. Importantly, one should remark that the assault of cities was not particularly common to nomadic warfare. In the case of the Revolt of Tacfarinas, Mazippa led his Moorish troops into irregular, highly mobile guerrilla warfare. ${ }^{22)}$ As Tacfarinas himself was not very successful in direct confrontations with Roman forces or in besieging even minor towns and strongholds, he also had to resort to hit-and-run strategies. ${ }^{23)}$ Therefore, the view that "the destruction of the towns recalls the behaviour of the interior tribesmen during the revolt of AD 6 and Tacfarinas" should be profoundly nuanced (Dyson 1975). The overall image of nomadic warfare is one of very frequent small-scale operations across the hinterland of sedentary nuclei. Also the short duration of the conflict may not accord with the general character of intermittent warfare between sedentary and (semi-)nomadic population segments in Roman Africa. This recurrent pattern may have resulted from the seasonal migrations of the nomads (Coltelloni-Trannoy 2002, Fishwick 1971).

Finally, Coltelloni-Trannoy provided another argument against a connection between the Revolt of Aedemon and the Roman struggle against Salabos, namely the geographical discrepancy between the destructions of the coastal cities and the

\footnotetext{
20) Plin. H. N. 5. 2.

21) Tarradell Tarradell, M. 1950. Las últimas investigaciones sobre los romanos en el N. de Marruecos. Zephyrus 1:49-56 - 1953a. Guía arqueológica del Marruecos español. Tetuán: Imprenta Cremades-. 1953b. "Nuevos datos sobre la guerra de los romanos contra Aedemon." I Congreso arqueologico del Marruecos español Tetuán, 1953b, pp. 337-344., Ponsich (1981, 136). Similar observations have been made by Ponsich, although at Jorf el Hamra a coin of Claudius may render a connection between the destruction and the Revolt of Aedemon rather improbable Ponsich, M. 1964. Exploitations agricoles romaines de la région de Tanger. Bulletin d'archéologie marocaine 5:235-252.. After the annexation of the client kingdom a military camp was built on the ruins of pre-Roman Tamuda (Villaverde Vega 1995). More recently, Lenoir has pointed out that the extent to which Lixus was razed, may have been overrated (1992, 271-3). One can question whether the revolt left its traces on the history of the city defences of Volubilis and Lixus, as they could have been damaged or created in this particular period. In fact, there were pre-Roman defence walls at Volubilis and Lixus, but archaeologists do not point to a connection between their creation with the Revolt of Aedemon (Tarradell 1960 161-4; Jodin 1965-66; Behel 1992). The destruction of the town walls at Volubilis have been connected with conflicts of the first century BC (Euzennat 1989, 208-10). However, Tarradell posed that the external facing of the western ramparts of Lixus can be dated to the reign of Claudius (1960, 162-3). These early constructions should not be confounded with those built during the second half of the second century AD around many urban centres in Tingitana (Rebuffat 1974).

${ }^{22)}$ Tac. Ann. 2. 52: Mazippa levi cum copia et incendia et terrorem circumferret.

${ }^{23)}$ Cf. Tacfarinas' failed assault on Thala and the subsequent change of strategy. Tac. Ann. 3. 21: Sed Tacfarinas perculsis Numidis et obsidia aspernantibus spargit bellum, ubi instaretur cedens ac rursum in terga remeans. Later, an attempt to take Thubuscum was just as unsuccessful. Tac. Ann. 4, 24. On the identification of this town with Thubursicu, cf. Syme (1951, 113-8). The inscriptions of Lepcis Magna which refer to dedications made at the conclusion of the Gaetulian War and the Revolt of Tacfarinas do not indicate whether the town itself or its hinterland had been threatened. Cf. AE 1940. 68.
} 
campaigns in the desert (2002). Against her view, Cassius Dio's characterisation of the military operations of Suetonius Paulinus and Hosidius Geta as the pursuit of fleeing enemies is hardly a persuasive counterargument.

According to Coltelloni-Trannoy "La situation, dans la future Maurétanie Césarienne, paraît étonnament calme" (2002). While the sources at our disposal are fairly scarce, they tend to show that Aedemon did not experience resistance in eastern Mauretania. On the other hand, the freedman may have chosen to seize Volubilis in order to establish an empire merely in what later would become Mauretania Tingitana. From a strategic point of view, this aim is fairly reasonable. The region was separated from the eastern part of Mauretania by mountain ranges through which no road may have led even in Roman times (Hamdoune 1995, Marion 1960, Talbert 2000, Thomasson 1982). Aedemon may have perceived this poorly accessible region as a relatively safe haven for his followers, which probably comprised (a part of) the royal military staff and their units as well as members of Ptolemaeus' court. ${ }^{24)}$ However, it seems that he only encountered resistance there.

\section{Aedemon and the Execution of Ptolemaeus}

I argue elsewhere that Ptolemaeus' removal may not have been motivated by Gaius' jealousy, but rather by the emperor's Realpolitik regarding the inefficiently governed protectorate. I also point to the observation that until the time Ptolemaeus was killed, the traditional procedure for the deposition of client kings (by exile) was being followed. A sudden event must have encouraged Gaius to change his mind and to get rid of Ptolemaeus. ${ }^{25)}$ Fishwick and Shaw have argued that the former client king was possibly involved in a conspiracy against the emperor (Fishwick and Shaw 1976). This may have occurred after he was deposed.

However, one should also consider the possible impact of the revolt in the process of deposing king Ptolemaeus. Plinius stated that Aedemon avenged Ptolemaeus. ${ }^{26)}$ While Rachet related that Aedemon merely intended to claim his place in the power vacuum, one should consider the possibility that Aedemon attempted to legitimise his ambitions by presenting himself as the avenger of the unjustly removed client king (Rachet 1970). In any case, the insurrection no doubt would have had serious consequences for Ptolemaeus if he was still alive. From Plinius' particularly concise statement, the date of the rebellion cannot be precisely determined. Did Aedemon decide to revolt when Ptolemaeus was in prison or sentenced to exile, or only when he heard that his former master had been killed? In the former case, it is feasible to assume that Gaius decided to command Ptolemaeus' death rather suddenly, upon hearing the news of an uprising in Mauretania.

\footnotetext{
${ }^{24)}$ It may be no surprise that, in later times, after the Arabian invasion, the Barghawata who populated the region were able to retain a high level of political and cultural autonomy Talbi, M. 1972. "Hérésie, acculturation et nationalisme des Berbères bargawata." Actes du premier congrès d'études des cultures méditerranéennes d'influence arabo-berbère, Malta, 1972, pp. 217-233.. It has been questioned whether the Barghawata were descendants of the Baquates Carcopino, J. 1940. La fin du Maroc romain. Mélanges d'Archéologie et d'Histoire de l'École Française de Rome 57:349-448- 1943. Le Maroc antique. La Suite des temps. Paris: GallimardGaland, L. 1948. Baquates et Bargawata. Hespéris 35:204-206.

${ }^{25)}$ For my argument cf. Vanacker (forthcoming).

${ }^{26)}$ Plin. H. N. 5. 11: ...Ptolemaeum regem a Gaio Caesare interemptum ulciscente liberto Aedemone...
} 


\section{Aedemon versus Crassus Frugi?}

Scholars have proposed that Gaius sent M. Licinius Crassus Frugi (cos. AD 27) to take the field against Aedemon and his followers (Pallu de Lessert 1896, Rachet 1970). After Gaius' execution, Claudius may have continued the legateship of Licinius Crassus Frugi in order to be able to receive the military decorations mentioned by Dio Cassius himself, although the war had already been finished (Coltelloni-Trannoy 2002, Gascou 1974). ${ }^{27)}$ Evidence for this hypothesis may be provided by the following inscription: ${ }^{28)}$

\section{M(arcus) Licinius / M(arci) f(ilius) Men(enia) / Crassus Frugi / pontif(ex) pr(aefectus) urb(i) / co(n)s(ul) leg(atus) / Ti(beri) Claudi Caesaris / Aug(usti) Ge[r]manici / in M[auretan]ia}

Since Suetonius relates that Licinius Crassus Frugi earned the ornamenta triumphalia for the second time for his exploits in Britannia in AD 43, it has been thought that the Revolt of Aedemon was the only event during which his first ornamenta could have been earned. ${ }^{29)}$

However, a number of objections counter the view that Aedemon's revolt was quelled by Licinius Crassus Frugi. Other solutions are possible for the lacuna in the final and most crucial line of the inscription. Thomasson proposed that the last line could have been M[oesia Acha]ia, followed by a lost line: [et Macedonia] (Thomasson 1996). Since Moesia, Achaia and Macedonia were governed by a legatus Augusti pro praetore until 44 AD, Licinius Crassus Frugi may have earned his first ornamenta while he was administrating these provinces sometime between AD 41 and $44 .{ }^{30)}$ Another argument against the involvement of Licinius Crassus Frugi in the conclusion of Aedemon's revolt is that Dio Cassius mentions Suetonius Paulinus and Hosidius Geta, but does not say a word about Frugi. ${ }^{31)}$ Furthermore, his report that the war in Mauretania was finished before Claudius acceded to supreme power seems to rule out the possibility that Licinius Crassus Frugi quelled the Revolt of Aedemon (Fishwick 1971). The theory that he was appointed by Gaius and then reassigned by Claudius is also fairly improbable. In all probability, Frugi and his relatives did not maintain a particularly good relationship with Gaius. This is attested by an anecdote about his son eliciting the emperor's anger when he adopted his ancestor's cognomen (Magnus). Furthermore, there are no other attestations of progress in his career during Gaius' reign. ${ }^{32)}$ Thus it is doubtful that this

\footnotetext{
27) Cf. D. C. 60. 8. 6.

28) CIL 6. $31721=$ AE 1973. $16=$ AE 1976. 17.

${ }^{29)}$ Suet. Claud. 17.6: ....M. Crassus Frugi equo phalerato et in veste palmata, quod eum honorem iteraverat.

${ }^{30)}$ During the first years of his reign, Claudius decided to divide this large administrative entity. Suet. Claud. 25 and 42, D. C. 60. 24. 1 Gaheis, A. 1899. Ti. Claudius Nero Germanicus. RE 3:27782839Mirković, M. 2007. Moesia superior. Eine Provinz an der mittleren Donau. Orbis provinciarum. Mainz am Rhein: Verlag Philipp von Zabern.. Thomasson's doubts are shared by Bénabou Bénabou, M. 1976. La résistance africaine à la romanisation. Textes à l'appui. Histoire classique. Paris: F. Maspero. and Gutsfeld Gutsfeld, A. 1989. Römische Herrschaft und einheimischer Widerstand in Nordafrika. Stuttgart: Franz Steiner Verlag.

${ }^{31)}$ Of course, one should not forget the lacuna in the literary tradition. D. C. 59. 25. 1.

${ }^{32)}$ Cf. D. C. 60. 5. 7-9, Suet. Calig. 35; Sen. Apocol. 11. 2.
} 
emperor gave him a legionary command in Mauretania. These observations are consistent with Suetonius' statement that eum honorem iteraverat. Apart from the possibility that he could have earned the ornamenta well before the reign of Claudius and Gaius, Frugi could have received them in AD 41 or 42 while governing Moesia, Achaia and Macedonia as a legatus Augusti pro praetore. If Licinius Crassus Frugi really governed Mauretania, he could only have done so in AD 41, or between 45 and 47. After all, he participated in the conquest of Britannia in AD 43 and was executed in AD 47, while Mauretania was governed by Suetonius Paulinus and Hosidius Geta in AD $42 .{ }^{33)}$ It should be noted that the first procurator of Tingitana appears in AD $44 .{ }^{34)}$

The absence of any attestation of a Roman general in Mauretania before the advent of Claudius is consistent with Plinius' statement that the Romans made war for the first time in Mauretania during the reign of Claudius. ${ }^{35)}$ Perhaps one should point to the possibility that the rebellion was quelled by pro-Roman groups among the local population, and not by the Romans themselves. This view reconciles both literary sources on this conflict, and is reinforced by the inscription that commemorates the actions of M. Valerius Severus at Volubilis. ${ }^{36)}$ It evokes the suggestion of Kotula, who, considering the phrase Aedemo / nem oppressum bello, concluded: "Peut-être doit-on imputer aux forces locales dirigées par Valerius Severus la victoire, non sans pertes d'ailleurs, sur les insurgés défendant le palais royal" (Kotula 1964). Finally, this would also explain Claudius' reluctance to follow the advice of his freedmen to accept the military decorations. It seems that if Licinius Crassus Frugi really was Claudius' legate in Mauretania in AD 41, he, like Claudius himself, could merely have earned his military decorations for reasons other than military virtue and glorious victories on the battlefield. ${ }^{37)}$

\section{Aedemon, Lusius Quietus and the Baquates}

Particularly interesting in respect of the Revolt of Aedemon is its possible connection with Lusius Quietus. As a commander of Moorish auxilia in the Roman army, he gained imperial prestige by his notable services in the Dacian Wars. A few years later, he was involved in the campaigns against the Parthians. ${ }^{38)}$ Eventually, he became governor of

\footnotetext{
${ }^{33)}$ On Suetonius Paulinus and Hosidius Geta, cf. supra. Frugi was probably executed together with his son in AD 47, cf. D. C. 60. 29. 6 (Zonar. 11. 9). Sen. Apocol. 11. $2+11.5+13.5$. Plutarchus incorrectly blamed Nero for the execution: Plut. Galb. 23.

${ }^{34)}$ In Tingitana. AE 1924. 66. Cf. Thomasson 1996, 225 [C1].

${ }^{35)}$ Plin. H. N. 5. 11. It should be noted that the absence of a Roman military intervention could have been delayed by the political crisis in Rome before and after Gaius' execution, though it is difficult to determine how much time separated the outbreak of the revolt from the emperor's death.

36) AE 1916. 42.

37) This hypothesis is supported by the view that Claudius seems to have been particularly liberal in respect of the attribution of military decorations. Cf. the case of Domitius Corbulo (PIR ${ }^{2}$ D 142), for building a canal between the Maas and the Rhine although Claudius bellum negavisset, and of Curtius Rufus (PIR ${ }^{2}$ C 1618), merely for constructing a (small) mine in Germania Superior (Tac. Ann. 11. 20). Cf. also Suet. Claud. 24. 3.

${ }^{38)}$ D. C. 68. 22. 2. On these wars and Lusius Quietus' role in them, cf. Strobel (2010, 221f., 236-85, 34881).
} 
Palestina and suppressed the Jews in the so-called Kitos War. ${ }^{39)}$ His actions made ancient historians rank him amongst the greatest generals of the Roman Empire. ${ }^{40)}$ However, the origins of this man of arms have been the subject of intense scholarly debate, especially in this journal. The discussion is rendered particularly complex by the allusion to Lusius Quietus as "the man of Qwrnyn" in an Arabian translation of Polemon's Physiognomonica. Qwrnyn has been perceived as Lusius Quietus' birth place, and has been situated both in Aethiopia and Africa Proconsularis. ${ }^{41)}$ Carcopino identified the place with Cyrene, and pointed to the possibility that Trajanus' general was linked with the city because he may have quelled a Jewish revolt there (1934). Carcopino's hypothesis is consistent with the statement of Dio Cassius: 'Lusius Quietus was a Moor and likewise ranked as a leader of the Moors'. ${ }^{42)}$ This view is strengthened by the similarities between the Moorish soldiers of (semi-)nomadic origin described by Strabo and the Moorish auxilia depicted on Trajanus' Column in Rome. ${ }^{43)}$ Most scholars have accepted Dio Cassius' statement as evidence that Lusius Quietus came from Mauretania. It seemed that one could not go beyond a general localisation. ${ }^{44)}$ Nevertheless, I believe the sources allow a more precise determination of the origins of Lusius Quietus.

The first clue can be derived from his name. While the cognomen "Quietus" appears rather infrequently in the sources, it has often been attested in North Africa, particularly in Africa Proconsularis (Kajanto 1965). His gentilicium is also fairly rare. According to Groag, one of his ancestors may have earned Roman citizenship as a prize for his support in the suppression of Aedemon. Groag assumes that this person was his father but, since almost eight decades separate the events of AD 40 and the death of Lusius Quietus (in late 117), it is more plausible that this ancestor should be identified as his grandfather. The citizenship was then conferred viritim and ob honorem by support of Lusius Geta, Claudius' praefectus praetorio, or Lusius Saturninus (cos. ca. AD 39-

\footnotetext{
${ }^{39)}$ Lusius Quietus (PIR ${ }^{2}$ L 439) as a cavalry commander in the Dacian War: D. C. 68. 8. 3; as governor in Judea, among others: D. C. 68. 32. 5, Eus. 4. 2. 5. The name of the Jewish revolt is derived from his cognomen.

40) Amm. 29. 5. 4.

${ }^{41)}$ Den Boer argued that Lusius Quietus was an Ethiopian den Boer, W. 1948. The Native Country of Lusius Quietus. Mnemosyne 1:327-337—. 1950a. Lusius Quietus III. Mnemosyne 3:339-343_. $1950 \mathrm{~b}$. Lusius Quietus, an Ethiopian. Mnemosyne 3:263-267.. Before him, Von Premerstein located his origins in Africa Proconsularis Von Premerstein, A. 1908. Das Attentat der Konsulare auf Hadrian. Klio (Beihefte) 8:1-88..

${ }^{42)}$ D. C. 68. 32. 4. Roos has countered the linguistic arguments of den Boer, which would point to the Ethiopian roots of Lusius Quietus Roos, A. G. 1950a. Lusius Quietus again. Mnemosyne 3:158-1651950b. Lusius Quietus. A reply. Mnemosyne 3:336-338..

${ }^{43)}$ Str. 17. 3. 7. Cf. also: Auct. B. Afr. 7. 5. Vulpe, who has studied Trajanus' column, related in respect of the scene depicting the charge of the Moorish cavalry: "They are irregular troops, a numerus of foreign warriors of the Roman army, fighting under the rule of their own chieftains, according to their customs in North Africa. We can see them bare-headed, with exotic faces, their hair falling in artificially curled tresses, wearing only short belted shirts, buttoned on the right shoulder. With the arms completely bare and bare-foot, they are riding without saddles or bridles, on small quick horses, of a certain breed, with wavy manes and long, wavy tails. The riders are carrying on the left small round shields and on the right, either in balance or ready to be flung, spears (painted, not extant)." Vulpe, R. 2002. Columna lui Traian, Trajan's column. Bucuresti: S.C. Daim P.H..

44) Also Iordañescu's view, that Lusius Quietus was born somewhere in the Atlas region, about $200 \mathrm{~km}$ south of the Roman limes, remains rather imprecise Iordañescu, A. 1941. Lusius Quietus. Bibliothèque d'Istros. Bucarest: Imprimerie Nationale..
} 
$44) .{ }^{45)}$ The ancestor would then have adopted the name of his supporter and (perhaps) patronus. In correspondence with the localisation of the setting of the military operations during the Revolt of Aedemon, Quietus' tribe should thus be situated in western Mauretania.

Further clues for the identification of the tribe are provided by the events in Mauretania that followed the discharge and execution of Quietus by Hadrianus. In the Historia Augusta, Lusius Quietus is said to have lost the trust of Trajanus' successor and was therefore deprived of his command over the gentes Mauri. These gentes Mauri I suggest were the indigenous tribes he ruled (quos regebat) in Mauretania. The deposition implied Lusius Quietus' loss of his prerogatives with regard to the command of the military units of his tribe in the Roman army. This led to the outbreak of a tumultus in Mauretania, which Marcius Turbo Fronto Publicius Severus was sent to suppress. ${ }^{46)}$ Lusius Quietus was subsequently accused of conspiring against Hadrianus and was executed. ${ }^{47)}$ Considering that the news of the execution of four conspirators of consular rank was met with indignation at Rome and that later Hadrianus blamed Attianus for its design, the reasons for the elimination may have been rather difficult to justify. ${ }^{48}$ ) According to Cassius Dio, the real causes of Lusius' execution were his wealth and fame, but according to Malloch, that explanation is stereotypical for this author (Malloch 2004). ${ }^{49)}$ Although the Historia Augusta provides some difficulty here, it seems that the campaign of Marcius Turbo was not yet finished at the time of Lusius Quietus' execution. ${ }^{50)}$ Most interestingly, motus Maurorum are said to have been subdued a little later, and for that reason, the emperor was granted supplicationes by the senate. ${ }^{51)}$ The organization of these celebrations suggests the gravity of the conflict. To what extent was the turmoil connected with the murder of Lusius Quietus? According to Iordañescu, Bénabou and Gutsfeld, the tumultus was probably not related to the death of the fallen general (Bénabou 1976, Gutsfeld 1989, Iordañescu 1941). Indeed, Carcopino posed that, instead, Hadrianus had to deal with a serious revolt of the Baquates. He has based his argument on the following inscription of Cartenna, which attests the efforts of C. Fulcinius Optatus to protect the town against an incursion of the Baquates: ${ }^{52)}$

$$
\begin{aligned}
& \text { C(aio) Fulcinio M(arci) f(ilio) Quir(ina) / Optato flam(ini) Aug(usti) IIvir(o) / } \\
& \text { q(uin)q(uennali) pontif(ici) IIvir(o) augur(i) / aed(ili) qu[ae]stori qui / }
\end{aligned}
$$

\footnotetext{
${ }^{45)}$ Lusius Geta (PIR ${ }^{2}$ L 435): Tac. Ann. 11. $31+33$. Cf. Groag Groag, E. 1927. Lusius Quietus. $R E$ 13:1874-1890. and, similarly, Charles-Picard Charles-Picard, G. 1959. La civilisation de l'Afrique romaine. Paris: Plon.. Lusius Saturninus (PIR² L 449), as proposed by Petersen Petersen, L. 1968. Lusius Quietus. Ein Reitergeneral Trajans aus Mauretanien. Das Altertum 14:211-217.: CIL 3. 8753. Also see: AE 1978. 137 = AE 1984. 228 = AE 1992. +272, and AE 1991. 438. Bussi Bussi, S. 2004. "Lusio Quieto: un "maghrebino" ai vertici dell'Impero." L'Africa romana. XVI convegno di studio. , Rabat, 2004, pp. 721-728 2. suggested a connection with Lusius Gallus (PIR ${ }^{2}$ L 434), tribunus militum of the Legio XXII Cyrenaica, which seems fairly improbable; cf. CIL 10. 4862.

46) Thomasson 1996, 199 [C8], PIR² M 249.

47) On these events: SHA. Hadr. 5. 8; 7. 1-2. Birley 1997, 78f and 87f.

48) SHA. Hadr. $7.3+9.3$.

49) D. C. 68. 32. 5. Cf. D. C. 59. 25.

50) SHA. Hadr. 6.7 vs. 7.3.

${ }^{51)}$ SHA. Hadr. 12. 7: motus Maurorum compressit et a senatu supplicationes emeruit. According to Birley, this grant points to the distinct possibility that Hadrianus personally intervened in the conflict (1997, 150).

${ }^{52)}$ CIL 8, 9663.
} 
inrup[ti]one Baqua / tium co[l]oniam tui / tus est [tes]timonio / decreti ordinis et / populi C[a]rtennitani / et incolae primo ipsi / nec ante ulli / aere conlato

The inruptio, which threatened both the inhabitants of the city itself and those of its vicinity (incolae), has been dated by Carcopino to the first half of the second century AD. His date was primarily based on epigraphic style, but also on the town's status visà-vis the socio-cultural habit of erecting statues (1940, 1943). Before Carcopino's suggestion, scholars were "...surtout désireux de combler les lacunes de notre tradition, l'ont ingénieusement, ingénument employée à cet effet: ils s'en ont servis comme d'une pierre pour boucher un trou dans l'histoire des campagnes qu'ils étudiaient, sans tenir compte de ce qu'elle nous enseigne par elle-même, de son aspect général, du trait final de son libellé" (Carcopino 1943). For instance, Thouvenot proposed that it was set up during the reign of Marcus Aurelius or Commodus (1939). A few decades earlier, Cagnat hesitantly dated the titulus to the reign of Septimius Severus (1912). The former associated it with the Moorish raids in Spain around AD 171 and 177. ${ }^{53)}$ The latter suggested that the Baquates who threatened Cartenna could have been the opponents of Tiberius Claudius Candidus when the latter exercised the function of dux terra marique I adversus rebelles hh(ostes) pp(ublicos) in Hispania Citerior. ${ }^{54)}$ Carcopino's arguments convinced most later scholars, and they are accepted here as well. ${ }^{55)}$ Considering the date of the inscription set up by Aelius Tuccuda at Volubilis (AD 140, AE 1931. 65), the hostilities should be traced back to the early years of Hadrian's reign. However, it has been accepted that Hadrianus had to deal with a revolt among the Baquates which had nothing to do with the fate of Lusius Quietus. ${ }^{56)}$ Bénabou suggested, though, an indirect connection with Lusius Quietus, posing that the rebellion was caused by the dissolution of his auxilia (Bénabou 1976).

The sources can be interpreted differently. I propose that Lusius Quietus was a chieftain of the Baquates, or a representative, and that therefore his forced resignation from his prerogatives and certainly his execution incited the tribe to revolt. Although Frézouls has doubted that the Baquates pastured their livestock on the land near Volubilis (cf. infra), it is clear that the tribe lived in Tingitana. Therefore, the hypothesis is consistent with the assumptions elaborated above, which point to the localisation of Quietus' tribe in western Mauretania. ${ }^{57)}$ The argument is supported by another observation. The

\footnotetext{
${ }^{53)}$ CIL 2-5. 783 = CIL 2. $2015=$ AE 1961. 340; CIL 6. $41140=$ AE 1934. $155=$ AE 1958. 26; CIL 2. 1120 (p. 838) = AE 1961. 339; SHA. M. Aur. 21. 1. SHA. Sev. 2. 4. On these incursions cf. Alföldy $(1985,101-6)$.

54) CIL 2. 4114

${ }^{55)}$ For instance, Harmand and Grenier Harmand, L., and A. Grenier. 1960. L'Occident romain: Gaule Espagne - Bretagne - Afrique du Nord (31 av. J.C. à 235 ap. J.C.). Bibliothèque historique. Paris: Payot., Rachet Rachet, M. 1970. Rome et les Berbères. Un problème militaire d'Auguste à Dioclétien. Collection Latomus. Bruxelles: Latomus., Bénabou Bénabou, M. 1976. La résistance africaine à la romanisation. Textes à l'appui. Histoire classique. Paris: F. Maspero., Frézouls Frézouls, E. 1980. Rome et la Maurétanie Tingitane: un constat d'échec? Antiquités africaines 16:65-93., Euzennat Euzennat, M. 1984. Les troubles de Maurétanie. Comptes Rendus de l'Académie des Inscriptions et Belles-Lettres 128:372393..

56) Frézouls, for instance, stated that the Baquates were conducting raids for the sole purpose of booty Frézouls, E. 1957. Les Baquates et la province romaine de Tingitane. Bulletin d'archéologie marocaine 2:65-115..

57) As will be discussed below, a more accurate localisation is difficult to assess Desanges, J. 1962. Catalogue des tribus africaines de l'antiquité classique à l'ouest du Nil. Université de Dakar.
} 
Historia Augusta does not specify whether Marcius Turbo Fronto was active in Caesariensis or Tingitana. Hence, it is definitely possible that he was charged with the government of both provinces. This was not an innovation. Evidently, Suetonius Paulinus and Hosidius Geta, who realised the pacification of Mauretania upon its annexation, acted as single commanders of the Roman forces (cf. supra), but also, around AD 85, the command of military units of multiple provinces was bestowed upon C. Velius Rufus, a dux exercitus Africi et Mauretanici. ${ }^{58)}$ In AD 75, after he had fulfilled the regular office of legatus Augusti pro praetore legionis III Augustae, Sex. Sentius Caecilianus was assigned the position of legatus Augusti pro praetore ordinandae utriusque Mauretaniae: ${ }^{59)}$

Imp(eratore) Caesare Vespasiano / Aug(usto) VI T(ito) Imp(eratore) Aug(usti) f(ilio) IIII co(n)s(ulibus) / Sex(tum) Sentium Sex(ti) f(ilium) Quir(ina) Caecilianum / leg(atum) Aug(usti) pro pr(aetore) ordinandae utri / usq(ue) Mauretaniae co(n)s(ulem) desig(natum) / coloni coloniae Iuliae Valenti / ae Banasae ex provincia nova / Mauretania Africa sibi liberis / posterisque eorum patronum / cooptaverunt / Sex(tus) Sentius Sex(ti) f(ilius) Quir(ina) Caecilianus / leg(atus) Aug(usti) propr(aetore) ordinandae utri / usque Mauretaniae co(n)s(ul) desig(natus) / colonos coloniae Iuliae Valen / tiae Banasae ex provincia no / va Mauretania ipsos liberos / posteros q(ue) eorum in fidem cli / entelamque suam suorumq(ue) / recipit egerunt legati / L(ucius) Caecilius Q(uinti) f(ilius) Fab(ia) Calvus // L(ucius) Sallustivs L(uci) f(ilius) Fab(ia) senex f(ilius)

The term ordinandae recalls the office of Ser. Sulpicius Galba, who was sent to Africa Proconsularis around AD 45 with a special mandate: Africam pro consule biennio optinuit extra sortem electus ad ordinandam provinciam et intestina dissensione et barbarorum tumultu inquietam (Suet. Galb. 7). ${ }^{60)}$ Galba's efforts in Africa contributed to his obtaining military decorations. ${ }^{61)}$ Hence, one should readily assume that Sentius Caecilianus also had a military assignment - the suppression of serious turmoil that affected both Mauretaniae or at least demanded the combined efforts of the military units stationed in both provinces, perhaps supported by legionary vexillationes.

The special command of Marcius Turbo Fronto may also have been necessary to deal with a revolt that threatened Roman control and authority in both provinces. Obviously, this could certainly have been the situation if he had to fight the Baquates: they dwelled in Tingitana but their assault on Cartenna proves that they (also) affected Caesariensis. Their highly mobile cavalry could pick out suitable targets within a particularly wide range of territory. Furthermore, this range could have been extended by the creation of temporary alliances. Ptolemaeus states that the Makanitae and the Ouakatae were part of

Publications de la section d'histoire. Dakar: Université de Dakar. Faculté des lettres et sciences humainesTalbert, R. J. A. 2000. Barrington Atlas of the Greek and Roman World. Princeton, N.J. ; Oxford: Princeton University Press,..

58) AE 1903. 368.

59) AE 1941. 79. CIL 9. 4194 also attests his previous assignment. Cf. Thomasson 1996, 135 [N5], 99 [C6].

${ }^{60)}$ Cf. also Tac. Hist. 1. 49, Plut. Galb. 3. 2. AE 1966. 595. Cf. Thomasson 1996, 35 [P1]

${ }^{61)}$ In addition to his exploits in Germania. Suet. Galb. 8: Ob res et tunc in Africa et olim in Germania gestas ornamenta triumphalia accepit... 
the Baquates. ${ }^{62)}$ Inscriptions from Volubilis bear witness to the dynamics that marked the formation of large (semi-)nomadic confederations. At times the Baquates were allied to the Macenites and the Bavares. ${ }^{63)}$

Three major objections can be raised against this reconstruction, yet none of them lead to its demolition. Firstly, it does not correspond with the traditional view of almost absolute hostility between Romans/sedentarists and nomads. According to a number of scholars, nomadic tribes were almost naturally hostile to the Romans, since their traditional socio-economic and political structure was constantly threatened by Roman political, social and fiscal policy. ${ }^{64)}$ However, there is plenty of evidence in favour of a view that nuances this antagonistic perception. T. Caesernius Statius Quinctius Macedo was a procurator of Mauretania Caesariensis in AD 107 and has been attested as a patronus of the tribe of the Maccues, who lived in this province. ${ }^{65)}$ Moorish auxilia are well attested in the Roman army. ${ }^{66)}$ Colloquia have been attested between Roman governors and the Baquates during the second and third centuries AD (Frézouls 1957). Romanelli (1962) and Frézouls (1980) have convincingly identified them as indications of a positive relationship between Rome and the indigenous tribe. ${ }^{67)}$ It seems that the inscriptions attest ceremonies which renewed a situation of peace and friendship each time a new leader was appointed. ${ }^{68)}$ This interpretation contrasts with the view, upheld

\footnotetext{
${ }^{62)}$ Ptol. Geog. 4. 1. 10.

63) This could have resulted from the demands of certain military endeavors or from dynastical developments. A federation with the Macenites: AE 1953. $78=$ AE 1957. 202; with the Bavares: AE 1942/43. $54=$ AE 1946. $52=$ AE 1946. 275, AE 1987. 1092, AE 1987. 1093.

64) Cf. Bénabou 1976, 69-72 and 90.

65) AE 1904. 150. On this governor: Thomasson 1996, 199 [C7], PIR² C 181.

${ }^{66)}$ Especially in Pannonia Inferior : AE 1999. 1260a-b, AE 2001. 1659, CIL 3. $3324=$ AE 1990. 825, CIL 3. 3444, CIL 3. 3542, CIL 3. 3545, CIL 3. 10673a-c + e, AE 1993. $1303=$ AE 2001. 1685a, AE 1982. $816=$ AE 2001. 1682, AE 1993. $1299=$ AE 2001. 1685f.

${ }^{67)}$ Cf. more recently: Weiß Weiß, A. 2002-2003. Die Grenzen der Integration: Rom und die Baquaten. Bonner Jahrbücher 202-203:335-346., Kuhoff Kuhoff, W. 1993. Die Beziehungen des römischen Reiches zum Volksstamm der Baquaten in Mauretanien. Arctos 27:55-71., Shaw Shaw, B. D. 1986. Autonomy and tribute: mountain and plain in Mauretania Tingitana. Revue de l'Occident musulman et de la Méditerranée 41-42:66-89., Christol Christol, M. 1987. "Rome et les tribus indigènes de la Maurétanie Tingitane." L'Africa romana. Atti del V convegno di studio, Sassari, 1987, pp. 305-337. Ibba and Traina Ibba, A., and G. Traina. 2006. L'Afrique romaine de l'Atlantique à la Tripolitaine, 69-439 ap. J.C. Collection Histoire ancienne et médiévale. Rosny-sous-Bois: Bréal. and Brahmi (2007, 163). Kolendo suggests that "les deux interprétations ne s'excluent pas" Kolendo, J. 2006. Les inscriptions de Volubilis et les relations diplomatiques entre les Romains et la tribu des Baquates. Textes et monuments. Archeologia 57:45-50.

${ }^{68)}$ The series begins with an unidentified princeps (ca. AD 169-176): CIL 8. $21826=$ AE 1894. $45=$ AE 1941. 115. Then Ucmetius follows (AD 173/175): AE 1953. 78 = AE 1957. 202. (Aurelius) Canarta (AD 180): AE 1953. 79 = AE 1957. 203. Ililasen (AD 200): AE 1957. 204, AE 1953. 80. Aurelius (?) (AD 226 ): AE 1987. 1092. Then a number of principes are attested who cannot be identified: (AD 223/232-234) AE 1942/43. $54=$ AE 1946. $52=$ AE 1946. $275=$ AE 1987. 1093 and $(A D 239 / 241)$ AE 1952. $42=$ AE 1953. $77=$ AE 1957. $201=$ AE 1987. 1090a = AE 1987. 1094 and (AD 241) AE 1952. 43. Sepemazin (AD 245): AE 1954. 110. Iulius Matif (AD 277): AE 1920. 44. Iulius Nuffusi (AD 280): AE 1921. 23. According to Shaw Shaw, B. D. 1986. Autonomy and tribute: mountain and plain in Mauretania Tingitana. Revue de l'Occident musulman et de la Méditerranée 41-42:66-89. and Weiß Weiß, A. 20022003. Die Grenzen der Integration: Rom und die Baquaten. Bonner Jahrbücher 202-203:335-346., in the last two inscriptions the procurator also communicated with the principes of the Baquates (respectively, Iulius Nuffusi and Iulius Mirzi). However, AE 1920. 44. seems to show that Iulius Nuffusi was the king's son (Iulius Matif), Iul(ii) Matif/ regis g(entis) Baq(uatium). AE 1921. 23. is fairly similar: Iulius Mirzi was the brother of Iulius Nuffusi, who by then had succeeded his father. Thus one should agree with
} 
by many scholars who aim for a maximalist reconstruction of instability and conflict in Roman Africa, that the tituli were attestations of conflicts. ${ }^{69)}$ Sigman argued that the timing of the "colloquium inscriptions" (i.e. autumn and spring) reveals that they were erected when the tribe descended to the plains. This can hardly be a surprise, since it cannot be expected that these colloquia took place when the (largest part of the) tribe was pasturing the flocks on higher ground. Following the traditional analysis, though, Sigman is convinced that their presence led to tensions, since Volubilis "was within the Baquates' winter pasture territory" (Sigman 1977). ${ }^{70)}$ According to Frézouls, however, the placement of these dedications at Volubilis could have been motivated primarily by the fact that the city was the region's most important administrative centre. One should not derive from the location of the tituli that the Baquates lived in the immediate vicinity of the city (Frézouls 1980). Frézouls' assumption is particularly useful, since scholars have struggled with the idea that the raids of the Baquates would have stretched over the entire distance from Volubilis to Cartenna. Deportation or migration theories should now be abandoned. ${ }^{71)}$ Nevertheless, one should concur with Hamdoune that the tribe's territory "dessine un vaste arc de cercle depuis le sud-ouest et jusqu'au nord-est de Volubilis" (1993). But while a more precise localisation is not possible, a considerable part of the Baquates also lived more closely to the river Moulouya, more to the (north)east of Volubilis. After all, Iulius Honorius wrote that this stream separated them from the Bavares. ${ }^{72)}$ The same river could also have been the theoretical border between Mauretania Tingitana and Mauretania Caesariensis, although it seems that the mountainous border zone was hardly under Roman control (Christol 1987, DondinPayre 2005, Hamdoune 1995). ${ }^{73)}$ These observations imply that the Baquates in fact lived at least partially outside the empire. Notably, Shaw has observed that similar colloquia were held between Rome and other peoples who lived beyond the limes (Shaw 1986).

Most interestingly, the location of the Baquates in the uncontrolled border zone between Caesariensis and Tingitana is consistent with the statement of Themistius about the origins of Lusius Quietus. ${ }^{74)}$ According to this fourth-century orator and philosopher, Trajanus' general came from outside the empire, from unconquered Libya. Of course, it

Kuhoff Kuhoff, W. 1993. Die Beziehungen des römischen Reiches zum Volksstamm der Baquaten in Mauretanien. Arctos 27:55-71. that Iulius Nuffusi and Iulius Mirzi were representatives of the kings of the Baquates. Only in AE 1953. 80. does Ililasen appear as princeps and successor (or rather co-ruler?) of his father, Uret.

${ }^{69)}$ For instance: Harmand and Grenier Harmand, L., and A. Grenier. 1960. L'Occident romain: Gaule Espagne - Bretagne - Afrique du Nord (31 av. J.C. à 235 ap. J.C.). Bibliothèque historique. Paris: Payot., Rachet Rachet, M. 1970. Rome et les Berbères. Un problème militaire d'Auguste à Dioclétien. Collection Latomus. Bruxelles: Latomus., Sigman Sigman, M. C. 1977. The Romans and the indigenous tribes of Mauretania Tingitana. Historia 26:415-439..

${ }^{70)}$ Similarly, Weiß 2002-2003, 342.

${ }^{71)}$ Contrary to Carcopino Carcopino, J. 1940. La fin du Maroc romain. Mélanges d'Archéologie et d'Histoire de l'École Française de Rome 57:349-448., Euzennat Euzennat, M. 1984. Les troubles de Maurétanie. Comptes Rendus de l'Académie des Inscriptions et Belles-Lettres 128:372-393., Gutsfeld Gutsfeld, A. 1989. Römische Herrschaft und einheimischer Widerstand in Nordafrika. Stuttgart: Franz Steiner Verlag., and Weiß Weiß, A. 2002-2003. Die Grenzen der Integration: Rom und die Baquaten. Bonner Jahrbücher 202-203:335-346..

${ }^{72)}$ Iul. Hon. A 47. Iulius Honorius confounds Barbares with Bavares.

${ }^{73)} \mathrm{Cf}$. the abovementioned absence of roads through the massif.

74) Them. Or. 16. 
is feasible to assume that since Roman power in Tingitana had been territorially reduced since the end of the third century Themistius may have transposed this situation of decreased Roman control to the past. ${ }^{75)}$ But it should be repeated that the presence of principes without citizenship even after the Constitutio Antoniniana definitely provides another indication of the location of the tribe's territory outside the zone of Roman control, indeed, at the empire's utmost periphery (Weiß 2002-2003).

Moreover, it should be mentioned that a funerary inscription commemorates the death of Memor in Rome in AD 180, son of Aurelius Canart(h)a, princeps Baquatium. ${ }^{76}$ While one may agree with Shaw (1986) that he may have been sent as a hostage to Rome after negotiations, it is also possible that he was in Rome for private reasons, perhaps in order to receive a proper education. ${ }^{77)}$ In any case, the attestation is another indication of (negotiated) harmony that usually marked the relationship between Rome and the Baquates.

A second counterargument against the hypothesis of a connection between Lusius Quietus and the Baquates can be derived from the Historia Augusta. The source suggests not one but two revolts occurred in Mauretania during the reign of Hadrianus. ${ }^{78)}$ The first attestation of conflict in Mauretania refers to a revolt that threatened Roman imperial control at the moment when Hadrianus took possession of imperial power. ${ }^{79)}$ Clearly, the author of Hadrianus' biography intended to enumerate the internal and external threats that were about to take place during this emperor's reign. This observation calls into question Iordañescu's view that the indications of conflicts dating to the first years of Hadrianus should be connected with attestations of unrest during the reign of Trajanus. Such a connection is rendered even more difficult to make if one considers the date of the last indication of military activity, that is to say a procurator pro legato of Mauretania Tingitana dated to AD 111-114. ${ }^{80)}$ The tumultus Maurorum is mentioned shortly after Hadrianus' accession to power, while the motus Maurorum were crushed around AD 122. Obviously, the existence of a second rebellion may cast doubt on the identification of Marcius Turbo Fronto's opponents with the revolting Baquates attested in Cartenna. However, there is no reason to suppose that the Baquates should rather be identified with the rebels of the second revolt. After all, epigraphic and archaeological evidence point to military operations in other parts of

\footnotetext{
75) The date of the last attestation of the colloquia (AD 280) should be connected with the reduction of the province during the reign of Diocletianus Corbier, P., and M. Griesheimer. 2005. L'Afrique romaine. 146 av. J.-C. - 439 ap. J.-C. Mondes anciens. Paris: Ellipses., though this reduction should not be overestimated (Marion 1967, 112-5; Rebuffat 1967, 52-4). Moreover, the archaeological record reveals that even inland towns like Volubilis continued to be inhabited and that "l'attachement des citadins à la civilization romaine ne perdure (...) jusqu'au VIe siècle" (Akerraz 1985, Lenoir 1983-1984 and 1985; quote: Hamdoune 1995, 253).

76) CIL 6. $1800=$ AE 1941. 118. Also his father participated at a colloquium, cf.: AE 1953. $79=$ AE 1957. 203.

77) The provision of a decent Roman education to the local elite's sons may well have been part of Roman integration policy, cf. Agricola's measures in Britain: Tac. Agr. 21. Similar institutions may be attested in Gallia, at the outbreak of the Sacrovir Revolt: Tac. Ann. 3. 43. Admittedly, these attestations merely give evidence of the organisation of such institutions in the provinces.

${ }^{78)}$ SHA. Hadr. 7. 1-2. vs. 12. 7.

${ }^{79)}$ SHA. Hadr. 5. 2: Mauri lacessebant. Contrary to Iordañescu 1941, 64-5.

${ }^{80)}$ P. Besius Betuinianus C. Marius Memmius Sabinus. Cf.: CIL 8. 9990. Thomasson 1996, 226 [T5], $\mathrm{PIR}^{2} \mathrm{~B} 112$
} 
Mauretania that can be connected with hostilities between Rome and other indigenous tribes. In AD 128 a castellum was constructed near Igilgili, while a few years earlier, in AD 122, a military camp was built at Rapidum. ${ }^{81)}$ The limitatio of the territory of the Zimises in AD 128 may recall the delimitation of the lands of the Musulamii after their defeat in the Gaetulian War and the Revolt of Tacfarinas. ${ }^{82)}$ The indigenous revolt around AD 122 may have been directed against Rome's intention to extend its power onto indigenous territory (Bénabou 1976). Most remarkably, the consolidation of Roman authority in Mauretania during Hadrianus' reign was realised with the support of auxilia from the semi-nomadic Musulamii in Africa Proconsularis. ${ }^{83)}$ But what is of major interest here, is the fact that it is feasible to suppose that one of these fortifications in Caesariensis, namely Praesidium Sufative, may well have been constructed to block incursions of western mountain tribes that could threaten eastern settlements like Cartenna. Perhaps it is no coincidence that the praesidium was constructed around AD $119 .{ }^{84)}$

Finally, one should consider the possibility that Marcius Fronto Turbo was sent to Dacia, where his skills were needed more badly, even before the rebellious Mauri were completely crushed. ${ }^{85)}$ A less illustrious governor could then have finished the task four years later. However, after Marcius Turbo's departure, the regular procuratorial administration was restored. L. Seius Avitus held the regular office of procurator in Mauretania Caesariensis around AD 119. ${ }^{86)}$ Unfortunately, the office of Q. Caecilius Redditus, governor of Mauretania Tingitana in AD 122, cannot be reconstructed. ${ }^{87)}$ It should be noted that the governor is attested on a military diploma, which may mark the end of the pacification process as it points to the demobilisation of soldiers.

A third objection can be deduced from Gutsfeld's statement that the Moorish tribesmen could not have been very enraged by the deposition or execution of Lusius Quietus, "den sie seit vielen Jahren nicht gesehen hatten" (1989). Therefore, this scholar considers fairly improbable the hypothesis that the revolts attested in the literature could have been inspired by the execution of the Moorish general. However, this is not a particularly strong argument. The colloquium inscriptions clearly indicate that to arrange external political affairs the principes of the Baquates made use of representatives who belonged to their direct kin group. Perhaps Lusius Quietus himself acted as a representative of an unknown princeps Baquatium, or ruled his tribe through his relatives. Furthermore, there is no reason to exclude the (admittedly implausible) possibility that he returned to his homeland between the Dacian Wars (AD 101-102 and 105-106) and the Parthian campaign (AD 114-117).

\footnotetext{
${ }^{81)}$ For the castellum at Igilgili, see: CIL 8. 8369; the camp at Rapidum: CIL 8. 20833, on the development of this camp and its civil community, see the extensive archaeological study of Laporte (1989).

${ }^{82)}$ Attestation of delimitation of the lands of the Zimises: CIL 8. 8369; of the delimitation of the territory of the Musulamii after the Bellum Gaetulicum: Oros. 6. 21. 18; after the Revolt of Tacfarinas: CIL 8. 22786a-1, CIL 8. 22789.

${ }^{83)}$ CIL 14. 4467, CIL 8. 4879.

84) $\mathrm{AE} 1913.157=\mathrm{AE} 1913 .+160=\mathrm{AE} 1985.984$.

85) SHA. Hadr. 6. 7, 7. 3.

86) AE 1913. 157 = AE 1985. 984. Cf. Thomasson 1996. 200 [C9], PIR ${ }^{2}$ S 314.

${ }^{87)}$ CIL 16. 169. Cf. Thomasson 1996, 227 [T7], PIR² C 71.
} 
It is known that Lusius Quietus was put to death in itinere. This could indicate that he was on his way to his homeland after he had been discharged. ${ }^{88)}$ No doubt one should acknowledge the boldness of the suggestion that Marcius Turbo may have been involved in the assassination of Lusius Quietus after the latter had disembarked in Mauretania, perhaps near Cartenna. Even if the dearth and nature of the sources makes us clutch at straws, however, it is reasonable to argue that there is a fair amount of evidence that defends the identification of the tribe of Lusius Quietus with the Baquates. Being a descendant of an indigenous chief of the Baquates who had supported the Roman cause during Aedemon's uprising, and himself a leader of the tribe or his representative, he was able to make a remarkable imperial career primarily based upon his military skills. It has been proposed that Hadrianus' decisions to deprive him from his political and military prerogatives, and finally from his life, provoked a serious revolt of the Baquates in Mauretania. If Lusius Quietus was indeed a descendant of a chieftain of the Baquates who cooperated with the Roman(-sided) forces at the time of Aedemon's uprising, then the rather positive relationship between Rome and the Baquates was particularly long-lasting. A votive inscription of Aelius Tuccuda, princeps of the Bauqates, attests that the good relations were restored as soon as Antoninus Pius ascended to the throne. Amity was maintained by repeated ceremonies until the end of the third century, when Roman power was reduced in Tingitana. The image of "les turbulents Baquates" (Rachet 1970) should clearly be adjusted, the "insubordination de ces terribles Maures" (Harmand and Grenier 1960) should be nuanced.

\section{Lusius Quietus and the integration of nomadic tribes in the Roman Empire}

The reconstruction elucidates the negotiated and highly discrepant relations between Rome and the (semi-)nomadic tribes in western North Africa. While the outcome of the Revolt of Aedemon was not particularly beneficial to its supporters, its merits lay in the provision of clues that illuminate the dynamic nature of these relationships, which should not be reduced to an account of antagonism and hostility. Contrary to what traditionalist scholars thought about the integration of North African nomads, the evidence concerning the Baquates and the Maccues does definitely not suggest that nomads were naturally hostile to integration, nor that Roman policy merely aimed at the inclusion of the sedentary while merely containing or expelling the nomad. ${ }^{89)}$ One of the most interesting stories that underscore the fluid and diverse relationship between nomads and Romans in North Africa, is that of the life and career of Lusius Quietus. Like the "colloquium inscriptions", it gives an indication of the significant role these leaders played in the creation and conservation of imperial loyalty. The diplomatic efforts comprising the recognition of the political power of tribal chiefs and the attribution of citizenship no doubt facilitated the establishment of Roman domination and succeeded in enfeebling tensions. ${ }^{90)}$

Yet Lusius Quietus' remarkable career itself and the revolt that ensued from his execution indicates how flexible our perspective on the integration of nomads in the Roman Empire should be. In contrast to such positive integration paths stand the highly

\footnotetext{
${ }^{88)}$ SHA. Hadr. 7. 2.

${ }^{89)}$ For the traditionalist view, see for instance Rachet 1970, Bénabou 1976.

90) Similar conclusions can be drawn from the famous Tabula Banasitana, attesting the attribution of Roman citizenship to a leading family of the Zegrenses. AE 1971. 534.
} 
turbulent episodes of Roman imperial history in western Mauretania during the third century. Especially the revolts at the time of the dissolution of the Legio III Augusta indicate that the importance of military power in the region continued to be a determinant factor in the establishment of the negotiated relationship between Rome and many (though not all) nomadic tribes in North Africa (Euzennat 1990, 579; BriandPonsart C. and Hugoniot C. 2006, 247-51). As Melani puts it in her study of the revolts in Caesariensis during the third century: "sembra che la consapevolezza o il sentore della debolezza della strutture imperiale avesse incoraggiato alla guerra" (Melani 1994).

No doubt influenced by different political and economic motivations, Roman policy towards the nomadic tribes throughout North Africa turned out to be diverse in nature, ranging from fairly negotiated to aggressively oppressive. Future research should care to explore the internal and external determinants that shape the specific integration trajectories of individual nomadic tribes, not merely in North Africa, but across the empire. Such a study could assess the particularity of the position of nomadic communities in Roman imperial history.

Akerraz, A., N. El Khatib-Boujibar, A. Hesnard, A. Kermorvant, E. Lenoir, and M. Lenoir. 19811982. Fouilles de Dchar Jdid 1977-1980. Bulletin d'archéologie marocaine 14:169-244.

Bénabou, M. 1976. La résistance africaine à la romanisation. Textes à l'appui. Histoire classique. Paris: F. Maspero.

Bussi, S. 2004. "Lusio Quieto: un "maghrebino" ai vertici dell'Impero." L'Africa romana. XVI convegno di studio. , Rabat, 2004, pp. 721-728 2.

Cagnat, R. 1912. L'Armée romaine d'Afrique et l'occupation militaire de l'Afrique sous les empéreurs. Paris: Leroux.

Carcopino, J. 1934. Lusius Quietus I'homme de Qwrnyn. Istros 1:5-9.

-. 1940. La fin du Maroc romain. Mélanges d'Archéologie et d'Histoire de l'École Française de Rome 57:349-448.

-. 1943. Le Maroc antique. La Suite des temps. Paris: Gallimard.

Charles-Picard, G. 1959. La civilisation de l'Afrique romaine. Paris: Plon.

Christol, M. 1987. "Rome et les tribus indigènes de la Maurétanie Tingitane." L'Africa romana. Atti del V convegno di studio, Sassari, 1987, pp. 305-337.

Coltelloni-Trannoy, M. 2002. Le royaume de Maurétanie sous Juba Il et Ptolémée (25 av. J.C. 40 ap. J.-C.). Études d'antiquités africaines. Paris: CNRS.

Corbier, P., and M. Griesheimer. 2005. L'Afrique romaine. 146 av. J.-C. - 439 ap. J.-C. Mondes anciens. Paris: Ellipses.

den Boer, W. 1948. The Native Country of Lusius Quietus. Mnemosyne 1:327-337.

-. 1950a. Lusius Quietus III. Mnemosyne 3:339-343.

-. 1950b. Lusius Quietus, an Ethiopian. Mnemosyne 3:263-267.

Desanges, J. 1962. Catalogue des tribus africaines de l'antiquité classique à l'ouest du Nil. Université de Dakar. Publications de la section d'histoire. Dakar: Université de Dakar. Faculté des lettres et sciences humaines.

Dondin-Payre, M. 2005. "Le gouvernement des provinces africaines du lle siècle au début du Ve siècle " in L'Afrique romaine de 69 à 439. Edited by B. Cabouret and M.-P. ArnaudLindet, pp. 119-143. Nantes: Éditions Le Temps

Dyson, S. L. 1975. Native revolt patterns in the Roman empire. Aufstieg und Niedergang der Römischen Welt 2:138-175.

Euzennat, M. 1984. Les troubles de Maurétanie. Comptes Rendus de l'Académie des Inscriptions et Belles-Lettres 128:372-393. 
Fishwick, D. 1971. The annexation of Mauretania. Historia 20:467-487.

Fishwick, D., and B. D. Shaw. 1976. Ptolemy of Mauretania and the conspiracy of Gaetulicus. Historia 25:491-494.

Frézouls, E. 1957. Les Baquates et la province romaine de Tingitane. Bulletin d'archéologie marocaine 2:65-115.

-. 1980. Rome et la Maurétanie Tingitane: un constat d'échec? Antiquités africaines 16:65-93.

Gaheis, A. 1899. Ti. Claudius Nero Germanicus. RE 3:2778-2839.

Galand, L. 1948. Baquates et Bargawata. Hespéris 35:204-206.

Gascou, J. 1974. "M. Licinius Crassus Frugi, légat de Claude en Maurétanie," in Mélanges de philosophie, de littérature et d'histoire ancienne offerts à P. Boyancé, Coll. de l'École franc. de Rome 22. Edited by s.n., pp. 299-310. Rome.

-. 1978. La succession des bona vacantia et les tribus romaines de Volubilis. Antiquités africaines 12:109-124.

Groag, E. 1927. Lusius Quietus. RE 13:1874-1890.

Gutsfeld, A. 1989. Römische Herrschaft und einheimischer Widerstand in Nordafrika. Stuttgart: Franz Steiner Verlag.

Hamdoune, C. 1993. Ptolémée et la localisation des tribus de la Tingitane. Mélanges de l'École Française de Rome. Antiquité 105:241-289.

-. 1995. "Frontières théoriques et réalité administrative: le cas de la Maurétanie Tingitane," in Frontières terrestres, frontières célestes dans l'antiquité. Edited by A. Rousselle, pp. 237-253. Paris: Presses Universitaires de Perpignan.

Harmand, L., and A. Grenier. 1960. L'Occident romain: Gaule - Espagne - Bretagne - Afrique du Nord (31 av. J.C. à 235 ap. J.C.). Bibliothèque historique. Paris: Payot.

Hoffman, M. 1959. Ptolemaios von Mauretanien. RE 23:1768-1787.

Ibba, A., and G. Traina. 2006. L'Afrique romaine de l'Atlantique à la Tripolitaine, 69-439 ap. J.C. Collection Histoire ancienne et médiévale. Rosny-sous-Bois: Bréal.

Iordañescu, A. 1941. Lusius Quietus. Bibliothèque d'Istros. Bucarest: Imprimerie Nationale.

Kajanto, I. 1965. The Latin Cognomina. Helsinki: Helsingfors.

Kolendo, J. 2006. Les inscriptions de Volubilis et les relations diplomatiques entre les Romains et la tribu des Baquates. Textes et monuments. Archeologia 57:45-50.

Kotula, T. 1964. Encore sur la mort de Ptolémée, roi de Maurétanie. Archeologia 15:76-94.

Kuhoff, W. 1993. Die Beziehungen des römischen Reiches zum Volksstamm der Baquaten in Mauretanien. Arctos 27:55-71.

Majdoub, M. 1992. "Nouvelles données sur la datation du temple C à Volubilis." L'Africa romana. Atti del X convegno di studio, Oristano, 1992, pp. 283-287 1.

Malloch, S. J. V. 2004. The Death of Ptolemy of Mauretania. Historia 53:38-45.

Marion, J. 1960. La liaison terrestre entre la Tingitane et la Césarienne. Bulletin d'archéologie marocaine 4:442-447.

Melani, C. 1994. Roma e le tribu della Mauretania Cesariense. Athenaeum 82:153-176.

Mirković, M. 2007. Moesia superior. Eine Provinz an der mittleren Donau. Orbis provinciarum. Mainz am Rhein: Verlag Philipp von Zabern.

Pallu de Lessert, A. C. 1896. Fastes des provinces africaines sous la domination romaine. Vol. 1. Paris: Ernest Leroux.

Petersen, L. 1968. Lusius Quietus. Ein Reitergeneral Trajans aus Mauretanien. Das Altertum 14:211-217.

Ponsich, M. 1964. Exploitations agricoles romaines de la région de Tanger. Bulletin d'archéologie marocaine 5:235-252.

Rachet, M. 1970. Rome et les Berbères. Un problème militaire d'Auguste à Dioclétien. Collection Latomus. Bruxelles: Latomus. 
Romanelli, P. 1959. Storia delle province romane dell'Africa. Istituto italiano per la storia antica. Studi fasc.14. Roma: L'erma di Bretschneider.

-. 1962. "Le iscrizioni volubilitane dei Baquati e i rapporti di Roma con le tribù indigene dell' Africa," in Hommages à Albert Grenier, vol. 3, Collection Latomus. Edited by M. Renard, pp. 1347-1366. Bruxelles: Latomus.

Roos, A. G. 1950a. Lusius Quietus again. Mnemosyne 3:158-165.

-. 1950b. Lusius Quietus. A reply. Mnemosyne 3:336-338.

Shaw, B. D. 1986. Autonomy and tribute: mountain and plain in Mauretania Tingitana. Revue de l'Occident musulman et de la Méditerranée 41-42:66-89.

Sigman, M. C. 1977. The Romans and the indigenous tribes of Mauretania Tingitana. Historia 26:415-439.

Talbert, R. J. A. 2000. Barrington Atlas of the Greek and Roman World. Princeton, N.J. ; Oxford: Princeton University Press,.

Talbi, M. 1972. "Hérésie, acculturation et nationalisme des Berbères bargawata." Actes du premier congrès d'études des cultures méditerranéennes d'influence arabo-berbère, Malta, 1972, pp. 217-233.

Tarradell, M. 1950. Las últimas investigaciones sobre los romanos en el N. de Marruecos. Zephyrus 1:49-56.

-. 1953a. Guía arqueológica del Marruecos español. Tetuán: Imprenta Cremades.

-. 1953b. "Nuevos datos sobre la guerra de los romanos contra Aedemon." I Congreso arqueologico del Marruecos español Tetuán, 1953b, pp. 337-344.

Thomasson, B. E. 1982. Zur Verwaltungsgeschichte Nordafrikas. Aufstieg und Niedergang der Römischen Welt 10:1-61.

-. 1996. Fasti Africani. Senatorische und ritterliche Amtsträger in den römischen Provinzen Nordafrikas von Augustus bis Diokletian. Stockholm: Paul Aströms Förlag.

Thouvenot, R. 1939. Les incursions des Maures en Bétique sous le règne de Marc-Aurèle. Revue des études anciennes 41:20-28.

Von Premerstein, A. 1908. Das Attentat der Konsulare auf Hadrian. Klio (Beihefte) 8:1-88.

Vulpe, R. 2002. Columna lui Traian, Trajan's column. Bucuresti: S.C. Daim P.H.

Weiß, A. 2002-2003. Die Grenzen der Integration: Rom und die Baquaten. Bonner Jahrbücher 202-203:335-346. 